\title{
Female entrepreneurs' gender roles, social capital and willingness to choose external financing
}

\author{
Xu Wang $^{1} \cdot$ Li Cai $^{1} \cdot$ Xiumei Zhu $^{1} \cdot$ Shengliang Deng ${ }^{2}$ (])
}

Received: 25 October 2018 / Revised: 26 July 2020 / Accepted: 28 July 2020 / Published online: 8 August 2020 (c) Springer Nature Limited 2020

\begin{abstract}
From the perspective of gender roles, this study uses social capital as the intermediary variable to study female entrepreneurs' willingness to choose external financing. We combine social and behavioral sciences and financing theory to explore interactions between gender roles, social capital, and willingness to choose external financing. We elaborate on the intermediary role of social capital between gender roles and external financing. We find differences in gender role types among female entrepreneurs that significantly impact their willingness to choose external financing. Further, the differences among gender role types of female entrepreneurs significantly impact their social capital, which in turn is a significant but not sole factor that mediates their willingness to choose external financing.
\end{abstract}

Keywords Female entrepreneurs $\cdot$ Gender roles $\cdot$ Social capital $\cdot$ External financing

\section{Introduction}

To create a new paradigm for economic development in today's changing global environment and vigorously promote mass entrepreneurship, China must implement an innovation-driven development strategy. Changes in the traditionally maledominated enterprise field are occurring quietly and female entrepreneurs have

Shengliang Deng

sdeng@brocku.ca

$\mathrm{Xu}$ Wang

wangxu@jlu.edu.cn

Li Cai

cli@jlu.edu.cn

Xiumei Zhu

xmzhu@jlu.edu.cn

1 School of Management, Jilin University, 5988 Renmin Street, Changchun 130022, China

2 Goodman School of Business, Brock University, 500 Glenridge Ave., St. Catharines,

ON L2S 3A1, Canada 
become a rapidly growing force that cannot be ignored. The Global Entrepreneurship Monitor (GEM) Report ${ }^{1}$ (2019) shows that the proportion of females in total early-stage entrepreneurial activity (TEA) in factor-driven economies reached its highest level compared to male TEA in 2018-2019, with the entrepreneurial activity index of Chinese female entrepreneurs being 9.3 and that of male entrepreneurs being 11.4. Chinese female entrepreneurs are even more active globally. According to the Hurun Report, more than $60 \%$ of the world's self-made female billionaires come from China (Hurun Report 2018). Despite the tremendous success of female entrepreneurs in the past decade, however, a 2016 survey of China's young female entrepreneurs found that $64.2 \%$ of them consider lack of funds to be the major difficulty in beginning an undertaking. Their enterprises and projects often cannot be supported by operating income; thus, they primarily rely on their own funds, private lending, or financial institutions. Most female entrepreneurs begin their own businesses with capital from their families and friends and apply for external financing such as bank loans only if their private savings are insufficient (Cai et al. 2005). Therefore, exploring the factors influencing female entrepreneurs' willingness to choose external financing is beneficial for female entrepreneurs, as this knowledge may allow them to expand their financing channels and thus achieve the success of their entrepreneurial undertakings.

Research on female-venture financing has drawn significant attention from scholars in the past two decades. Several studies have claimed that gender discrimination against women exists in bank borrowing (Fay and Williams 1993; Iakovleva et al. 2013; Becker-Blease and Sohl 2007; Marlow and Swail 2014). However, many other scholars doubt that such discrimination exists. They argue that there is no clear evidence of gender discrimination in lending by financial institutions. Female entrepreneurs themselves, however, do in fact perceive discrimination (Fabowale et al. 1995; O'Gorman and Terjesen 2006; Eddleston et al. 2014). As a result, gender roles, which reflect entrepreneurs' psychological traits and behavior styles from a gender perspective, have attracted researchers' attentions. In this study, we attempt to combine gender role theory with financing theory to explore the distribution of gender role types among female entrepreneurs, and how gender roles influence female entrepreneurs' willingness to choose external financing. To explore the relationships between gender roles, social capital, and willingness to choose external financing, we also use social capital as the connection between gender roles and a willingness to choose external financing.

The paper is structured as follows: The next section sets out the theoretical background for proposing several hypotheses related to gender roles, social capital and willingness to choose external financing. In doing so, we analyze the special characteristics of female entrepreneurs in the Chinese context. The methodology used to

\footnotetext{
1 The TEA national index is computed as the proportion of respondents classified as nascent entrepreneurs in a representative national sample. Each individual in the sample is classified as either an entrepreneur or non-entrepreneur based on his or her responses to the questions $q 1$ to $q 3$ in the GEM survey, i.e. $\mathrm{q} 1$ whether the individual is currently involved in a start-up (indication of being nascent entrepreneur), $\mathrm{q} 2$ whether their current job involves a start-up (nascent intrapreneur), and $\mathrm{q} 3$ whether the individual is the owner/manager of a new business (owner/manager).
} 
test the empirical data is subsequently described, followed by a presentation of the research findings. The paper concludes with a summary discussion in which theoretical contributions and managerial implications are discussed, as well as the study's limitations and suggestions for much needed future research.

\section{Literature review and hypotheses development}

\section{Theoretical background}

Research on external financing from the perspective of entrepreneurs' gender can be primarily divided into two streams. The first states that biological sex does have an impact on access to external financing. Much anecdotal evidence confirms the difficulties of women in accessing external financing. Female entrepreneurs receive significantly less angel investment than male entrepreneurs (Becker-Blease and Sohl 2007). Based on a fear of borrowing, female entrepreneurs prefer to seek funding from family and friends (Verheul and Thurik 2001). Businesses in which women hold majority ownership are significantly less likely to seek external equity capital (Orser et al. 2006). Zhang et al. (2016) also found that more than $80 \%$ of venture capital funding for female entrepreneurs in the Jiangsu Province of China is their own. However, the second stream argues that there is no difference between male entrepreneurs and female entrepreneurs in accessing external financing, and that access to external financing cannot be explained from the perspective of biological sex. Some scholars have discovered that neither male nor female entrepreneurs have had significant gender-discrimination in terms of funding sources (O'Gorman and Terjesen 2006). While there are few detected gender differences with respect to perceptions and behavior about funding, women obtain significantly less financial capital to develop their new businesses, and the lower levels of financial capital that women business founders achieve are associated with slower early growth compared with their male counterparts (Alsos et al. 2006). After considering the capital structure of start-up companies, Fabowale et al. (1995) claim that there is no proof of gender discrimination in the actual practices of financial institution lending, but that female entrepreneurs do indeed have a perception of gender discrimination. Thus, there is no consensus on the impact of biological sex on the financing of entrepreneurs, but both research streams suggest that female entrepreneurs have an awareness of a financing barrier that may be more psychological rather than actual.

Based on the studies of financing from the perspective of biological sex, scholars have extended research into the field of gender roles. According to Li (2012), gender does not affect entrepreneurship; the significant influence on entrepreneurship is each individual's degree of identification with a gender role, that is, the code of conduct compliant with his or her gender that is gradually formed during his or her life. Gender roles are the reflection of everyone's gender traits at the psychological level (Bem 1974). The existing research on gender roles focuses mainly on the field of psychology and can be divided into three primary models. First, individual entrepreneurs whose internalized gender qualities match their own physiology have a healthier mental state and a greater advantage in interpersonal communication; 
this is the uniform model (Terman and Miles 1936). The second is the androgynous model. In 1974, psychologist Bem formally proposed the concept of an androgynous gender role, in which masculinity and femininity are independent and interdependent. Based on the relative personality traits of the two genders in an individual, Bem (1974) proposes four gender role types: masculinity (masculine traits are dominant), femininity (feminine traits are dominant), androgyny (both traits are significantly dominant) and undifferentiated (both traits exist but are not dominant). The androgynous model proposes that there is no conflict between masculinity and femininity; individuals with an androgynous gender role have the healthiest state of mind and the fewest barriers to interacting with people at different levels. They, therefore, get along harmoniously with others. The third is the masculine model. Derived from the androgynous model, this model assumes that individuals with a masculine gender role have the healthiest state of mind, and that the mental state of individuals with the androgynous gender role is dominated by masculine traits. A significant negative correlation exists between masculine characteristics and interpersonal distress, and the correlation between feminine characteristics and interpersonal distress is not significant (Liu 2009). Currently, the uniform model has been largely sidelined due to its lack of association with social reality in the contemporary world (Constantinople 1973; Pleck 1987). For the past three decades, most scholars have focused their studies on primarily the androgynous and masculine models. The commonality between the two models is that gender roles can significantly affect entrepreneurs' mental health status, which significantly affects interpersonal relationships. The controversial question about these two models is whether masculine traits play a decisive role in an individual's mental health.

In addition to research on the influence of gender, research on other factors influencing entrepreneur financing include human capital, social capital, and psychological capital. Research on social capital has gained most prominence (Portes and Sensenbrenner 1993). Portes (1998) proposes that social capital is the ability to access resources from social networks. Social capital is not an individual's fixed assets but his or her assets in interpersonal social relationships while gender is a marker of social status in the entrepreneur-financer relationship. Thus, social capital influences the bank-firm relationship and, consequently, resource acquisition and small-business performance (Saparito et al. 2013). Studies have revealed that social capital is useful in three ways for entrepreneurs to obtain financing. First, a good bank-enterprise or government-enterprise relationship makes financing more convenient. The duration of the enterprise-bank collaboration, and the number of banks that companies cooperate with, each have a significant impact on not only their ability to obtain bank financing but also the amount (Petersen and Rajan 1994). A correlation also exists between the government-enterprise linkage and the scale of bank loans. In Pakistan, the number of bank loans for enterprises with a relationship to government is twice that of enterprises without this relationship (Khwaja and Mian 2005). Another study shows that gender plays a role, not only as differences between male and female entrepreneurs, but also and more importantly in the interaction between entrepreneurs and investors, where venture types, human and social capital, investor and partner relations, etc., are constructed 


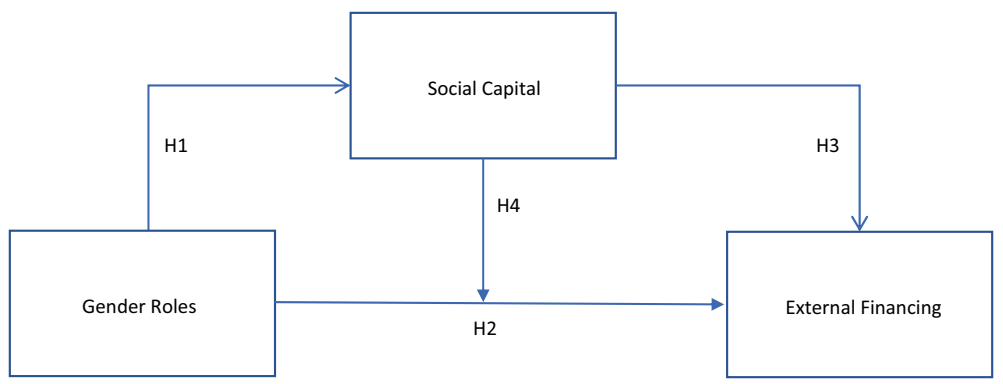

Fig. 1 Conceptual model

as gendered (Alsos et al. 2017). Second, social capital can effectively reduce information asymmetry and provide credit guarantees that facilitate access to informal financing. Informal borrowers can rely on the business, interpersonal, and geographical relationships among the business partners to obtain relevant information to effectively avoid information asymmetry and decrease financing obstacles (Lin and $\mathrm{Su} 2005$ ). In addition, a reputation mechanism is built into social networks, which makes borrowers afraid of undermining credit in their social networks and of the "social sanctions" that result if they do not repay their loans (Impavido 1998). As a result, the repayment rate of loans from social networks is higher than that of loans from regular channel without personal relationship. It can be seen that social capital can significantly affect access to financing. However, female entrepreneurs' social networks are dominated by strong relationships with families and friends. They lack the key connections and tools to establish business-related social networks. Research also shows that women shape their business objectives and growth expectancies based on different socialization experiences. Thus, a more nuanced approach is needed by women-owned businesses to realize their full growth potential (Manolova et al. 2007). Additionally, women use their kin to a larger extent than men (Greve and Salaff 2003). Therefore, entrepreneurial capital for females comes primarily from themselves, their families, and friends.

The existing literature has shown that gender roles of entrepreneurs can significantly affect their mental health and communication skills, and that their social networks can significantly affect access to financing (Liu 2009; Khoury et al. 2013; Iakovleva et al. 2013; Saparito et al. 2013; Eddleston et al. 2014; Marlow and Swail 2014). However, few studies are focused on the relationships among gender roles of female entrepreneurs, their social capital, and their willingness to choose external financing. By studying the differences between social capital and willingness to choose external financing in various types of female gender roles and exploring the effect of social capital on female gender roles and financing choices, this paper reveals how the characteristics of female entrepreneurs and external social capital impact female entrepreneurs' financing (See Fig. 1). 


\section{Gender roles and social capital}

Differences exist in gender role types among female entrepreneurs. In one of several empirical studies of entrepreneurs' gender roles, Li (2012) found that among females, the proportion of feminine gender roles is less than $25 \%$, and the proportion of masculine and androgynous gender roles exceeds $50 \%$. Compared with the average female population, masculine characteristics are more prominent in female entrepreneurs. Liu (2008) revealed that Chinese female entrepreneurs have obvious characteristics of the androgynous gender role. They are reluctant to be considered non-feminine yet are not willing to be labeled weak or incompetent. In contrast, American female entrepreneurs have obvious characteristics of the masculine gender role; they do not consider women's management style inferior to men's but show independent, strong and decisive traits with a sense of competition.

There are clear differences in gender roles in terms of communication skills and these differences further affect entrepreneurs' social networks, in three ways. First, gender role types display significant differences in the scale of their social networks. In both same- and opposite-gender interactions, the androgynous gender role has more advantages than other types (Wang 2011). Burleson et al. (1992) find that people with the ability to recognize and understand the emotional states of others and sustain others' points of view are more likely to be accepted by peers. Therefore, during social interactions, individuals with stronger personal communication ability encounter fewer barriers, have smoother interactions with people of different personalities at different levels, and have less difficulty in expanding their social networks. Second, different gender roles display significant differences in the quality of interpersonal relationships. Existing studies have found that feminine and masculine gender roles each have different priorities in terms of interaction quality. Individuals whose gender roles have more obvious masculine traits meet fewer obstacles in interpersonal relationships ( $\mathrm{Li} 2016)$ while those with androgynous gender roles (which include both femininity and masculinity) have the best interaction quality and the lowest level of social anxiety (Xu et al. 2014). Individuals with the androgynous gender role have the highest degree of interpersonal harmony. Meanwhile, masculinity and interpersonal harmony are also closely and positively related (Wang 2012); put differently, the stronger the masculinity, the more harmonious the interpersonal relationship. Finally, gender role types also display significant differences of trust in social relationships. Our thorough research on the relationships between trust, masculinity, and femininity found that masculinity is significantly and positively related to the confidence and dependence levels of interpersonal trust, and that femininity is significantly and positively related to the predictable level of interpersonal trust (Wei 2014). In their gender role research, Lavine and Lombardo (1984) find that androgynous participants disclose their intimate personal relationships to their parents and best friends the most, followed by the traditional (masculine and feminine) participants while the undifferentiated participants disclose the least. Androgynous females especially, who are both highly masculine and highly feminine, disclosed their intimate personal relationship to friends the most. (Shaffer et al. 1991). Considering that individualized trust tends to coincide with increased self-disclosure (Steel 
1991), individuals with androgynous gender roles have the highest level of interpersonal trust.

As Bourdieu (1986) points out, social capital means relationships, resources, and assets embedded in social networks. It is believed therefore that human trust can greatly enhance social capital through better access to resources via quality relationships (Fukuyama 1995). Currently, three approaches exist in the literature on social capital theory. The "resource theory" states that social capital gains resources through social networks (Nahapiet and Ghoshal 1998). The "network theory" argues that a social network itself is social capital (Zhang and Chen 2002). The "characteristics theory" stresses the trust and mutual benefits of social capital (Putnam 1993). Our research combines the arguments of the above three approaches to determine what gender roles help gaining social capital through social network. Therefore, we propose hypothesis 1:

Hypothesis 1a Gender roles significantly influence how female entrepreneurs access social capital.

Hypothesis 1b Androgyny and masculinity show significantly higher impact on the social capital attainment than femininity.

\section{Gender roles and willingness to choose external financing}

Behavioral psychologists believe that the study of human behavior must begin from internal needs and motivation (Watson 1930). In their early stage of startups, female enterprises face various capital needs to cover expenses. Financing is often required. Differences in personality and motivations cause individuals to choose from several methods of obtaining financing. Through studying the influence of masculinity and femininity on entrepreneurial self-efficacy, Li (2012) concludes that individuals with an androgynous gender role have the highest self-efficacy, that masculinity have a major impact on self-efficacy, and that female entrepreneurs with higher self-efficacy are more inclined to accept external financing (Guan and Luo 2009). In terms of motivation, masculinity is significantly and positively related to achievement, and the correlation between masculinity and achievement motivation is stronger than that between femininity and achievement motivation (Wang 2006). Based on a theoretical analysis, Yao et al. (2012) proposes the notion that entrepreneurs with higher achievement motivation are more inclined to seek external equity financing. From this reasoning, we can speculate that the gender role types of female entrepreneurs have a significant impact on their willingness to choose external financing. Therefore, we propose hypothesis 2 :

Hypothesis 2a Gender roles have a significant impact on female entrepreneurs' willingness to choose external financing.

Hypothesis 2b Masculinity exerts significantly higher influence on the willingness to choose external financing than femininity. 


\section{Social capital and willingness to choose external financing}

Social capital can effectively reduce the financing constraints on enterprises; the bank-enterprise relationship mitigates the constraining effect on financing of both private and state ownership of enterprises. The social capital of enterprises has a greater effect on easing financing constraints in less institutionalized areas (Ma 2010). Moreover, social capital can reduce the financing cost for enterprises (Khoury et al. 2013). The relevant theoretical model proposed by Zhao et al. (2013) suggests that social networks transmit information and support financing, both of which help decrease the costs of credit and capital management in enterprise financing. Social capital can reduce the information asymmetry between enterprises and financing institutions, and also broaden information channels and improve members' ability to search for non-public information (Burt 1997). In addition, social capital enhances cultural identity and emotional support between entrepreneurs and investors. Members of the same social network tend to have experience and expertise in similar industry sectors. As a result, members who share a common background or life experience often show strong emotional support to each other, and thus it is more likely that investors who recognize a common cultural identity will form a bond (Lin 2006). Therefore, effective interpersonal relationship based on social network may facilitate access to external financing if financial institutions and venture capitalists are part of this social circle. Thus, we propose hypothesis 3 :

Hypothesis 3 Social capital has a significantly positive impact on female entrepreneur willingness to choose external financing.

\section{The intermediary role of social capital}

Social capital provides the interface to connect gender role types of female entrepreneurs and their willingness to choose external financing. Different types of gender roles influence the level of social capital of female entrepreneurs and in turn influence their willingness to choose external financing in three ways. First, gender roles can significantly affect the scale of social capital. If social capital is large, less information asymmetry exists in the financing process, and female entrepreneurs display more willingness to choose external financing. Second, gender roles can significantly affect the relationship intensity of social capital. Relationship intensity of social capital can effectively reduce financing constraints during the financing process, resulting in more willingness by female entrepreneurs to choose external financing. Finally, gender roles can significantly influence trust in social relationships. It has been found that the level of intimate personal relationship disclosure varies among different gender roles (Lavine and Lombardo 1984) and also results in different levels of individual trust (Steel 1991). With increased trust in social relationships, the cost of financing becomes lower, which in turn can effectively enhance female entrepreneurs' willingness to choose external financing. Recently, empirical data has emerged to support the contention that social capital indeed impacts 
external financing in different ways (Guiso et al. 2004; Javakhadze et al. 2016; Ferris et al. 2019). Accordingly, we propose hypothesis 4:

Hypothesis 4 Social capital shows positive intervening effect between gender roles of female entrepreneurs and their willingness to choose external financing.

\section{Sample and methodology}

\section{Sample selection}

We used a questionnaire to collect data. Before we administered the survey; we did a pretest of the designed questionnaire among eight female entrepreneurs to make any necessary adjustment in terms of questionnaire structure and language. The final paper questionnaire was then distributed to female Master of Business Administration (MBA) students ${ }^{2}$ of the School of Management at Jilin University, and the online questionnaire was later distributed to female customers of venture capital firms and female entrepreneurs of network research institutes of China. The MBA students who received paper questionnaires were instructed not to participate in the online survey to avoid duplications. The companies included were limited to small and medium sizes, and they are geographically dispersed across Northern China. A total of 220 questionnaires were issued (20 to female MBA students and 200 online to female entrepreneurs) and 170 were returned. After invalid questionnaires are excluded, we obtained a sample of 150 effective questionnaires (18 from female MBA students and 132 from online).

\section{Study variables and measurements}

\section{Gender roles}

This paper defines gender roles as the characteristics or qualities of people that satisfy certain expectations of society, resulting from the influence of a particular social context and their biological sex (Bem 1974, 1977). This study measures gender role variables by drawing on related questions in the Bem Sex-role Inventory revised by $\mathrm{Lu}$ and $\mathrm{Su}$ (2003) based on the specific situation of China. Those who score higher than average on the masculinity scale are classified as masculinity while those who score higher than average on the femininity scale are classified as femininity. Those who score higher than average on both masculinity and femininity scales are classified as androgyny while those who score below average on both masculinity and femininity scales are classified as undifferentiated (Spence et al. 1975; Bem 1974, 1977). Respondents were asked to rate the 26-item questionnaire ${ }^{3}$ (Bem 1974, 1977;

\footnotetext{
2 The MBA students primarily work full time, either as business owners or senior managers.

3 See a complete list of items, please refer to the questionnaire by Bem 1974, 1977; Lu and Su 2003.
} 
$\mathrm{Lu}$ and $\mathrm{Su} 2003$ ) on the gender role types using a 7-point Likert scale to describe themselves from 1 (not at all) to 7 (completely).

\section{Social capital}

To measure the intermediary variable of social capital, this study draws on the index of social networks designed by Zhu and Fei (2010), but makes appropriate changes based on the characteristics of female entrepreneurs. The measure consists of three scales, namely relationship scale, relationship intensity and relationship trust. ${ }^{4}$ These scales measure the respondents' long-term relationship with relatives, financial institutions, other enterprises and government agencies and the trust between them. Again, the respondents were asked to rate the 15-item questionnaire on the social networking using a 7-point Likert scale to describe their own situations from 1 (not at all) to 7 (completely).

\section{External financing}

Existing research on the measurement criteria of external financing is relatively mature. In designing related questions for this study, we used the criteria for measurement of financing approaches that are generally accepted by academia (Denis 2004; Ayyagari et al. 2008; Zhang and Li 2013). This variable consists of 11 items on how female entrepreneurs obtained their investment financing. These 11 items measure the ratio of external equity financing, external debt financing and policy financing. ${ }^{5}$ The respondents were asked to rate from 1 (low) to 7 (high) on the ratio of their investment funding sources.

\section{Control variables}

We used entrepreneur's education background, age, firm size, industry type and regional economy level as control variables, consistent with prior researches (Jun et al. 2019; Williams and Grégoire 2015; Rienda et al. 2013; Plotnikova et al. 2016). Based on our survey results, three education levels were used to describe the respondents' education background. We categorized our respondents into 3 age groups and 4 industries. Firm size was controlled by numbers of employees as a measure. For further regression analysis, variables above were transferred into dummy variables. Besides, we used Regional Economic Development Index to measure regional economy level variable (Wang et al. 2017).

\footnotetext{
${ }^{4}$ Please refer to Zhu and Fei (2010) for the original list of measurement items.

5 Please see a full list of items by Ayyagari et al. (2008), Zhang and Li (2013).
} 
Table 1 Validity testing

\begin{tabular}{llll}
\hline Gender roles & \multicolumn{2}{l}{ Kaiser-Meyer-Olkin measure of sampling adequacy } & 0.933 \\
\cline { 2 - 4 } & Bartlett's test of Sphericity & Approx. Chi-square & 4656.611 \\
& & Df & 325 \\
\hline Social capital & Kaiser-Meyer-Olkin measure of sampling adequacy & Sig & 0.000 \\
& Bartlett's test of sphericity & Approx. Chi-Square & 1956.092 \\
& & Df & 105 \\
External financing & Kaiser-Meyer-Olkin measure of sampling adequacy & Sig & 0.000 \\
& Bartlett's test of sphericity & Approx. Chi-square & 0.887 \\
& & Df & 55 \\
& & Sig & 0.000 \\
\hline
\end{tabular}

\section{Validity and reliability}

We conducted reliability and validity testing of the collected research data. The Cronbach's alpha coefficients of scales regarding gender role, social capital, and intention to seek external financing are $0.982,0.955$ and 0.949 respectively, indicating that the reliability of the results is very satisfactory. Results from a Kaiser-Meyer-Olkin (KMO) test on the scales of gender role, social capital, and intention to seek external financing are $0.933,0.857$, and 0877 , i.e. all greater than 0.8 . Factor analysis indicates that loading of each question is greater than 0.5 , indicating validity of the data (See Table 1). In order to test the stability of the measure, we randomly selected 18 samples from the online respondents to compare with 18 samples from the MBA class respondents. Then a $t$-test was employed to assess the reliability of the measures. No significant differences were found across all the measures in the study. Furthermore, we compared 20 early returns with 20 last returns via $T$-test. No significant differences were found across all the measures in the study, indicating a high level of reliability and stability of the study instrument.

Finally, for any self-reported survey research, common method error is always a concern, no matter how careful the research is designed. To eliminate any possible bias of common method variance associated with self-report surveys, a Harman single-factor test (Podsakoff et al. 2003) was conducted on items related to dependent and independent variables; no general factor in unrotated factor structure emerged. The first (largest) factor accounting for only $30 \%$ of the total variance. Thus, common method variance is unlikely to be a serious threat to the findings of the current study. 
Table 2 Sample distribution

\begin{tabular}{lrr}
\hline Gender role & $N$ & $\%$ \\
\hline Masculinity & 13 & 8.7 \\
Femininity & 11 & 7.3 \\
Androgyny & 63 & 42.0 \\
Undifferentiated & 63 & 42.0 \\
Total & 150 & 100.0 \\
\hline
\end{tabular}

\section{Empirical results}

\section{Descriptive statistics and correlation}

Our sample shows the following characteristics. The mode of academic qualifications of entrepreneurs is 3.0, indicating that the entrepreneurs' educational levels are primarily vocational school and college. The age range of the sample is primarily between 35 and 45 and the industries are primarily traditional. Companies led by these female entrepreneurs show the following main characteristics: the number of employees is between 50 and 100, the annual operating income is between one and two million RMB, and the total assets are between one and 20 million RMB. In addition, using the median classification approach for gender roles of our study sample, we obtain the following results. With the median classification approach for gender roles, we categorized our sample into 4 types of gender roles as Table 2 shows. The highest proportion of the entire sample are women with androgynous or undifferentiated gender roles $(42.0 \%$ each), followed by women with masculine gender roles $(8.7 \%)$. Women with feminine gender roles were the lowest proportion $(7.3 \%)$.

Table 3 reports means, standard deviations and correlations of study variables. There exist significant and positive correlations between masculinity, femininity, androgyny, social capital and willingness to choose external financing, which lend significant support to our argument that gender roles significantly influence how female entrepreneurs access social capital and androgyny and masculinity show significantly higher impact on the social capital attainment. One surprising finding from the correlation table is that femininity has a stronger and more significant correlation with willingness to choose external financing than masculinity, which runs counter to previous study findings that female entrepreneurs are risk averse and less inclined to engage external financing for fear of rejection (Shin et al. 2019). Of course, to be willing to seek external financing is different than to be able to attain external financing. Abundant previous studies support the fact that female entrepreneurs receive significantly less external financing (Verheul and Thurik 2001; Orser et al. 2006; Becker-Blease and Sohl 2007). To decipher this phenomenon, the following analyses were conducted to learn the insights.

To test our research hypotheses, we employed three sets of statistical methods, one-way analysis of variance (ANOVA), regression and the bootstrap approach. The results are presented below. 


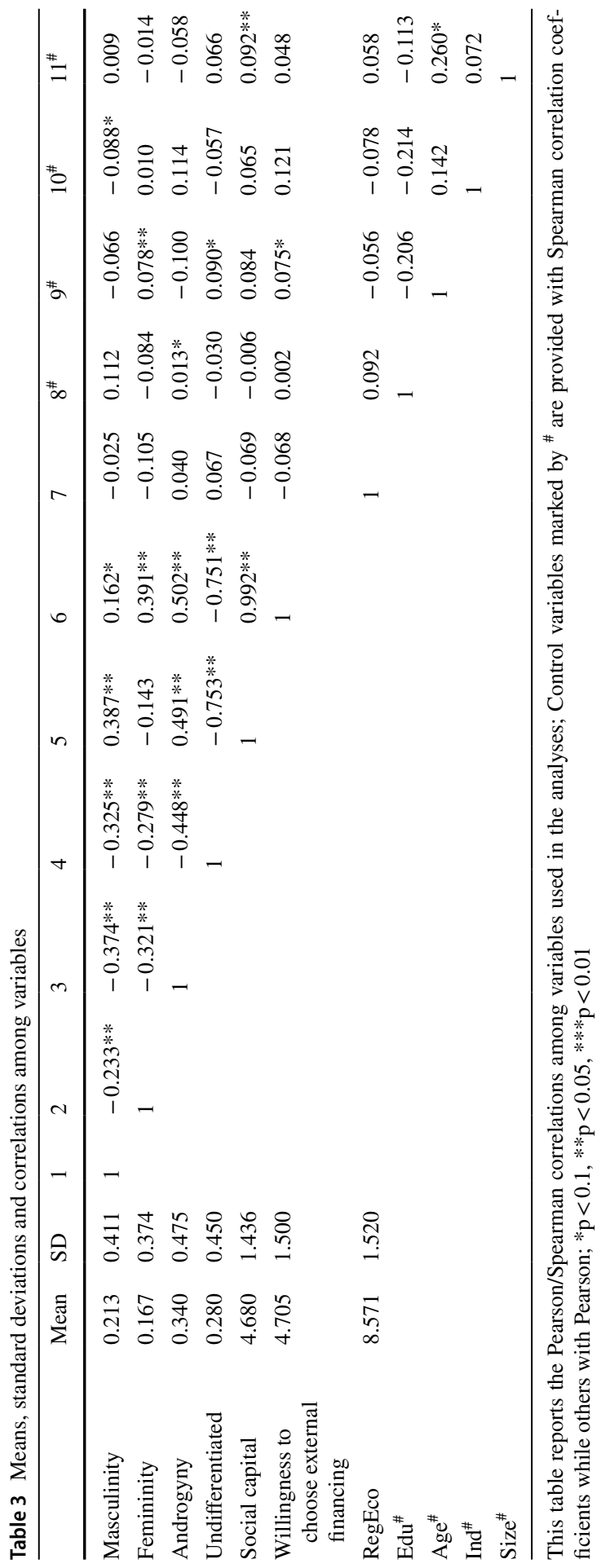

站 


\section{Testing of hypothesis 1}

In this study, the independent variable (gender roles) is a four-category variable, and the dependent variable is a continuous variable. ANOVA was adopted to determine whether there are significant differences among gender role types. First, the test of homogeneity of variance shows significant results at the 0.001 level. Next, we conducted a preliminary analysis of the differences in social capital related to willingness to choose external financing by the four gender role types. The results of the ANOVA are as follows. In terms of the dependent variables of social capital and willingness to choose external financing, the $F$ values of the overall $F$ test are 105.827 $(P=0.000<0.001)$ and $123.655(P=0.000<0.001)$ respectively, with both reaching significant levels. This indicates that gender role types have a significant impact on female entrepreneurs' social capital and willingness to choose external financing, thus supporting hypotheses 1a. To further examine whether there are significant differences among the gender role types in terms of their impact on social capital and willingness to choose external financing, this study employed Tamhane's T2 method to conduct multiple post hoc comparisons. The test results are shown in Table 4.

Regarding social capital, significant differences exist between groups of female entrepreneurs with the androgyny and groups with femininity and undifferentiated $\left(0.136^{*}\right.$ between the feminine and androgynous groups and $2.404 * * *$ between androgynous and undifferentiated groups), and significant differences are displayed between the feminine and undifferentiated groups $\left(2.268^{* * *}\right)$ as well as between the masculine and undifferentiated groups $\left(2.310^{* * *}\right)$. This result indicates that significant differences are present among different gender roles in terms of their impact on social capital. In contrast, the social capital of individuals with the androgynous gender role is significantly higher than that of individuals with the feminine and undifferentiated gender roles but is not significantly different from that of individuals with the masculine gender role. Individuals with the undifferentiated gender role have the lowest social capital. The empirical results further support hypothesis 1a that gender roles significantly influence how female entrepreneurs access social capital as well as hypothesis $1 \mathrm{~b}$ that androgyny and masculinity show significantly higher impact on the social capital attainment than femininity.

Furthermore, the regression results also corroborate the ANOVA results. As shown in regression models 1 and 3, masculinity and androgyny both have a significant impact on social capital at the 0.001 level, with regression coefficients of 1.296 and 1.522 respectively, thus further supporting hypothesis 1a. Further, femininity with a coefficient of -0.526 does not show any significant contribution to social capital attainment. The empirical results show further support to hypothesis $1 \mathrm{~b}$, which state that androgyny and masculinity show significantly higher impact on the social capital attainment than femininity.

\section{Testing of hypothesis 2 and 3}

Regarding willingness to choose external financing, significant differences exist. The ANOVA results indicate that the mean difference between the masculine and 


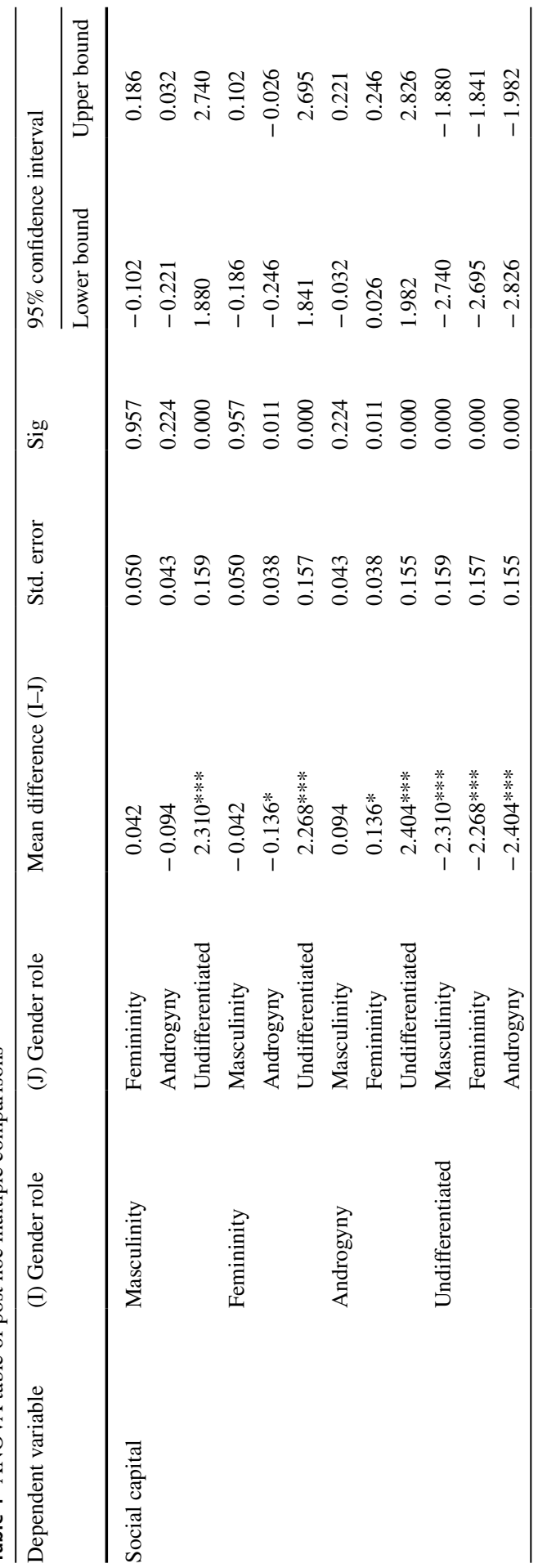

s. 


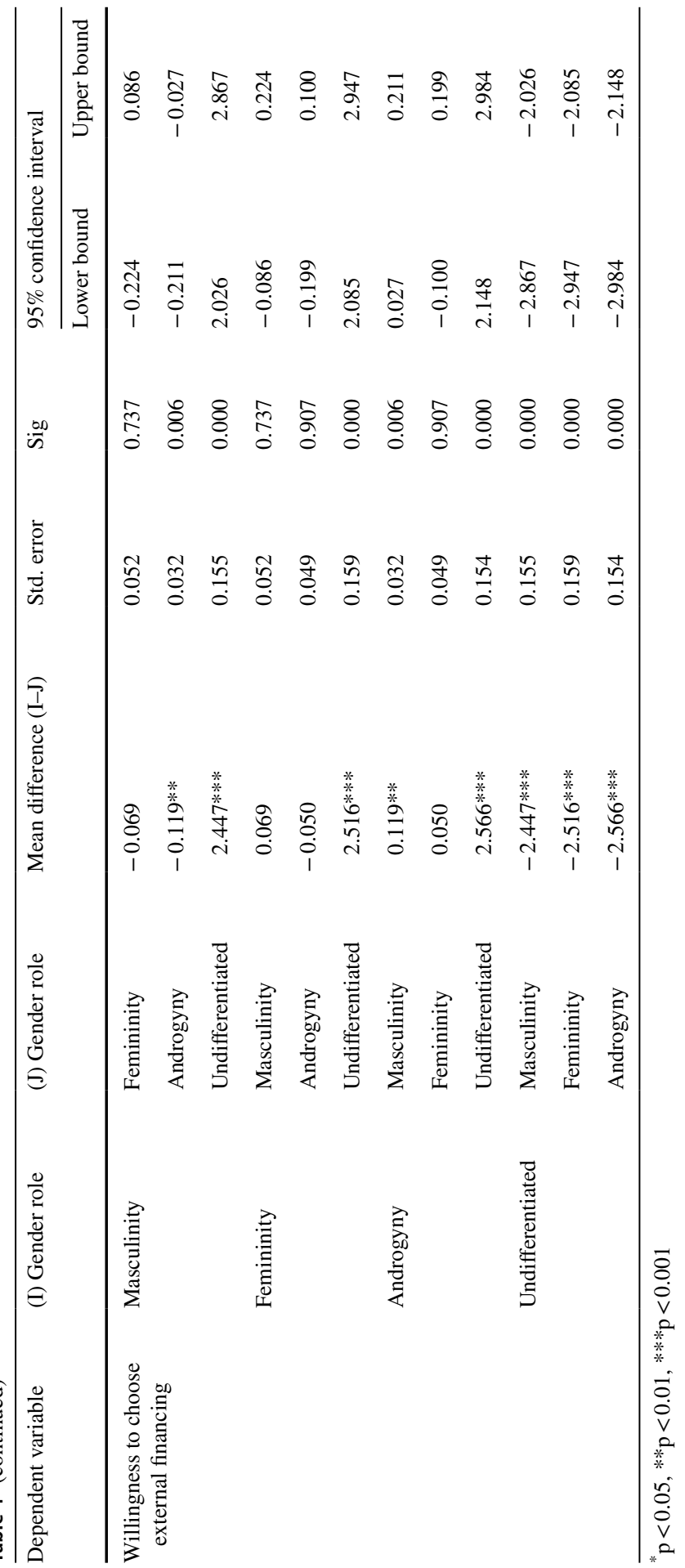


androgynous groups is $0.119 * *$ while between the androgynous and the undifferentiated groups it is $2.566 * * *$. In the feminine and undifferentiated groups, the difference is $2.516^{* * *}$ and there is also a significant difference between masculine and undifferentiated groups at $2.447 * * *$. This result indicates that significant differences are present among different gender roles in terms of willingness to choose external financing. Relatively speaking, the willingness to choose external financing by individuals with androgynous gender roles is higher than that of individuals with masculine and undifferentiated gender roles but is not significantly different from that of individuals with feminine gender roles. Individuals with an undifferentiated gender role are least willing to choose external financing. The empirical results further support Hypothesis 2a, which states that gender roles have a significant impact on female entrepreneurs' willingness to choose external financing. However, the results failed to support hypothesis $2 \mathrm{~b}$. Female entrepreneurs with strong femininity actually show strong willing ness to choose external financing.

To further test the hypotheses, we run a regression analysis by using androgyny, masculinity, femininity and undifferentiated as the independent variables while social capital and willingness to choose external financing as the dependent variables (see Table 5). In terms of willingness to choose external financing, regression models 8 and 9 show that both femininity and androgyny have significant effects on female entrepreneurs' willingness to choose external financing at the 0.001 level, with regression coefficients of 1.362 and 1.620, respectively, thus supporting hypothesis $2 \mathrm{a}$. However, the contribution of femininity is actually higher than that of masculine. The empirical results further reject hypothesis $2 b$, which states that masculinity exerts significantly higher influence on the willingness to choose external financing than femininity.

In regression model 6 , social capital demonstrates a high significance with a regression coefficient of 1.035 at 0.001 significance level, indicating that social capital has indeed a significant and positive impact on female entrepreneurs' willingness to choose external financing. Thus, hypothesis 3 is supported. Finally, when social capital is introduced into regression model 12, the explanatory power of four independent variables are all impacted, implying that there is an intervening power of social capital. To further verified this intervening power, we conducted further analysis as follows.

\section{Testing of hypothesis 4}

We used the bootstrap approach for intermediary-effect testing to determine whether intermediary paths exist as well as verify the intermediary effects of multi-classification independent variables and multiple intermediary variables (Zhao et al. 2010). In recent years, the bootstrap approach has been widely used in research fields such as psychology and other social and behavioral sciences (Preacher and Hayes 2004; Dawn 2008). For input to a bootstrap analysis program, we established the following three dummy variables: masculinity and androgyny, femininity and androgyny, and undifferentiated and androgyny. The bootstrap sample is set to 5000, and the empirical results at the $95 \%$ confidence interval (CI) are shown in Table 6. The 


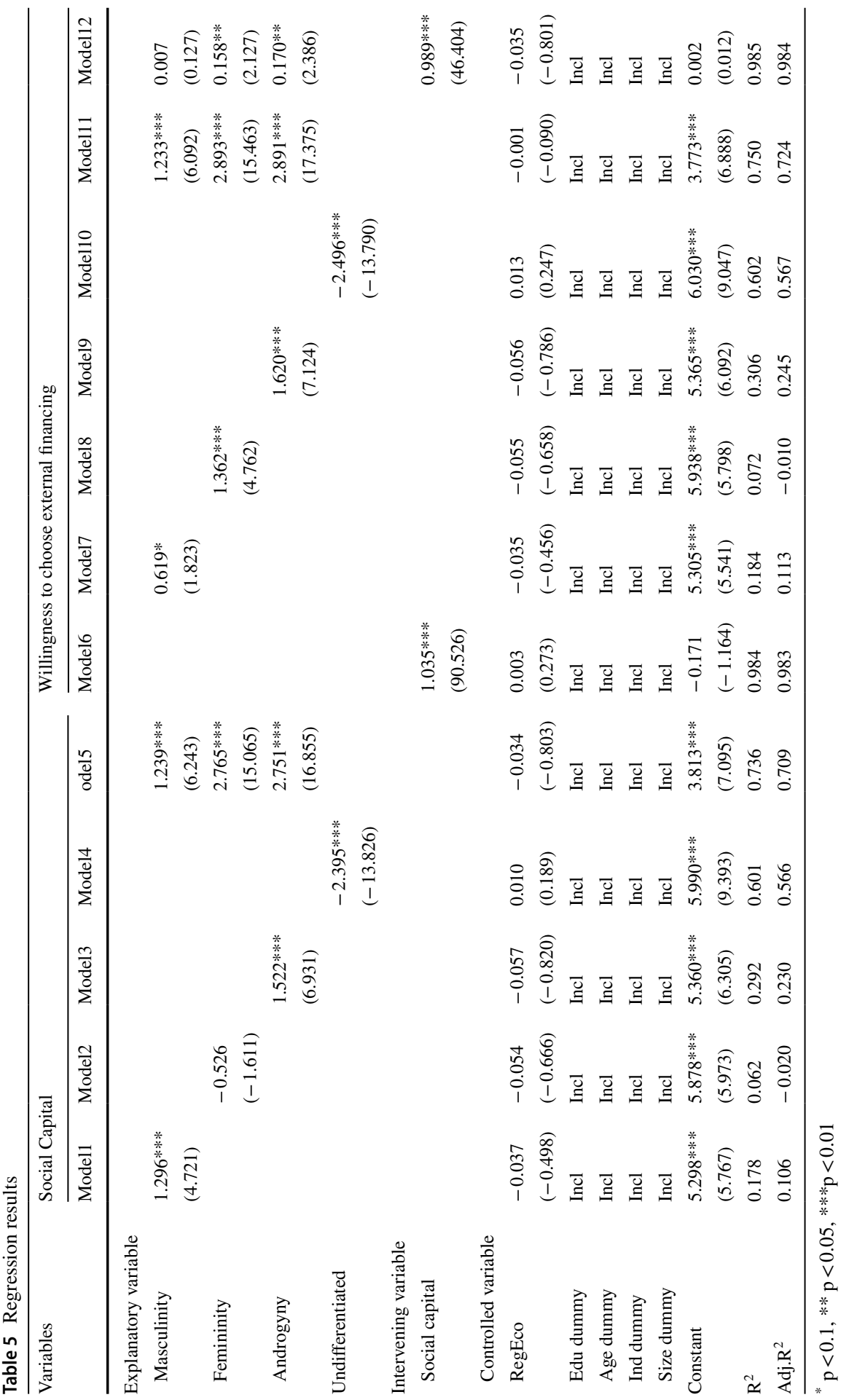


Table 6 Intermediary effect testing with Bootstrap

\begin{tabular}{llll}
\hline Variable & Effect size $(\mathrm{a} \cdot \mathrm{b})$ & S. E & Bootstrap (95\%, CI) \\
\hline Masculinity and androgyny & $1.061^{*}$ & 0.133 & $(0.804)-(1.325)$ \\
Femininity and androgyny & $0.994^{*}$ & 0.131 & $(0.750)-(1.263)$ \\
Undifferentiated and androgyny & $-2.290^{*}$ & 0.150 & $(-2.591)-(-2.001)$ \\
\hline
\end{tabular}

$* \mathrm{p}<0.05, * * \mathrm{p}<0.01, * * * \mathrm{p}<0.001$

Table 7 Intermediary effect testing with Bootstrap

\begin{tabular}{lcccc}
\hline Variable & Effect $\left(\mathrm{c}^{\prime}\right)$ & S. E & T value & P value \\
\hline Masculinity and androgyny & 0.004 & 0.057 & 0.076 & 0.939 \\
Femininity and androgyny & $0.130^{*}$ & 0.060 & 2.168 & 0.032 \\
Undifferentiated and androgyny & $-0.251^{* * *}$ & 0.052 & -4.797 & 0.000 \\
\hline
\end{tabular}

${ }^{*} \mathrm{p}<0.05, * * \mathrm{p}<0.01, * * * \mathrm{p}<0.001$

degrees of the intermediary effect of social capital on willingness to choose external financing in terms of masculinity and androgyny, femininity and androgyny, and undifferentiated and androgyny are 1.061 (95\%, CI 0.804 to 1.325$), 0.994$ (95\%, CI 0.750 to 1.263$)$ and $-2.290(95 \%, \mathrm{CI}-2.591$ to -2.001$)$, respectively. The intervals do not contain 0 , proving that $a^{*} b$ is significant and statistically meaningful. Therefore, social capital is an intermediary between gender roles and willingness to choose external financing. In addition, the direct effect of the dummy variable of masculinity and androgyny $(P$ value $=0.939>0.05)$ on the dependent variable of willingness to choose external financing is not statistically significant, implying that in the case of the masculinity group, social capital has the sole intermediary role between gender roles and willingness to choose external financing. In comparison, the direct effect of the dummy variables of undifferentiated and androgynous roles $(P=0.000<0.001)$ and feminine and androgynous roles $(P=0.032<0.05)$ on the dependent variable of willingness to choose external financing is statistically significant (See Table 7 ). The $a \cdot b \cdot c^{\prime}$ values of both dummy variables are positive, indicating that social capital has a partial intermediary role between the undifferentiated and feminine role groups and willingness to choose external financing, thus supporting hypothesis 4 . However, it is still possible that we may have missed other complementary intermediary elements.

\section{Discussion and conclusion}

The primary findings of this study are as follows. Gender roles have a significant influence on female entrepreneurs' social capital attainment and their willingness to choose external financing. Various gender role types show significant differences in these two aspects. Androgyny has the highest impact on social capital attainment 
as well as on willingness to choose external financing. Meanwhile, masculinity has a higher contribution to social capital attainment, and femininity has a higher contribution to female entrepreneurs' willingness to choose external financing. In addition, social capital is an intermediary between gender role types and female entrepreneurs' willingness to choose external financing, but it may not be the only intermediary factor (Fischer et al. 1993). There may be still unknown complementary intermediary factors between undifferentiated individuals, feminine individuals, and female entrepreneurs' willingness to choose external financing.

China, a country under poverty with a mere GDP per capital of $\$ 290$ four decades ago, has grown to become the second largest economy in the world today with an impressive run of 30 years' double-digit growth. Since 1980s when China started to transition from a planned economy to a more market-based economy, China benefitted greatly from its factor endowment of abundant cheap, yet skilled labor supply. China indeed has become the manufacturing hub of the world. However, with rising wages, China's competitive advantage based on skilled cheap labor has started to fade and its economy started to slow down in the past 5 years. Faced with a global challenge, especially the trade war with United States and Covid-19 pandemic which push China's economic growth into negative territory for the first time in 40 years, China is now looking for alternative economic growth engine to achieve a sustainable development. Entrepreneurship and innovation are the logical answer (Schumpeter 1947; Liu and Froese 2020; Wu et al. 2020). This research is a reflection of China's effort to boost the grassroots entrepreneurship to again incentivize its economic growth. Female entrepreneurs, still underrepresented, are a special economic power force to be cultivated (Wang et al. 2011).

\section{Theoretical and practical implications}

This study has both theoretical and practical implications. Our major theoretical contribution lies in the fact that this research connects both gender roles and social capital with external financing. Past researches have mainly focused on the impact of gender roles in the field of psychology and behavior sciences (Constantinople 1973; Bem 1977; Lavine and Lombardo 1984; Pleck 1987; Steel 1991; Xu et al. 2014). Although researches on gender roles started to appear in the field of management and finance in the past 10 years, these researches primarily focused on investigating whether gender roles impacted external financing. While some researchers do argue that there is a gender bias towards female entrepreneurs in accessing external financing (Becker-Blease and Sohl 2007), others rejected this claim through their empirical findings (O’Gorman and Terjesen 2006). However, no prior research has provided an explanation as why female entrepreneurs do receive considerably less external financing, a fact that both streams of researchers acknowledged. Furthermore, few prior researches have supplied a solution as how to facilitate female entrepreneurs' access to external financing other than government policy intervention. Meanwhile, the past decade also witnesses an increased interest in the study of social capital in management field. Recently, empirical data has emerged to support the contention that social capital indeed impacts external financing in different ways 
(Guiso et al. 2004; Javakhadze et al. 2016; Ferris et al. 2019). However, these prior researches failed to connect social capital with gender roles to investigate external financing issues. Our research brings in the concept of social capital to connect gender roles with external financing. Our empirical data does provide some insights as to why female entrepreneurs receive considerably less external financing although they are very willing to explore external financing. It is not simply because they are female entrepreneurs who lack the desire for external financing. On the contrary, our study findings actually show that female entrepreneurs with strong feminine traits do express a higher degree of willingness to choose external financing. They are not really risk averse to reject external financing as we previously suspected. The fact that they receive considerably less external financing is due to that they possess far less social capital (social network and social trust) than their male counterparts (Guiso et al. 2004). To improve female entrepreneurs' success in accessing external finance, they must improve their social capital which exhibits a strong positive intervening effect on the relationship between gender roles and willingness to choose external financing. Our research findings indicate that androgyny and masculinity have the highest impact on social capital. In another word, we discovered that a lack of social capital is the underlined reason why female entrepreneurs received far less external financing. To improve female entrepreneurs' access to external financing, they must develop either strong androgynous or masculine traits which are most conducive to building a stronger and broader social capital and better access to external financial resources. The least desirable gender role type is the undifferentiated which contributes little to social capital or access to external financing.

Practical implications include the following. First, average female entrepreneurs may lack confidence in achieving return on investment, and they are often less willing to expand their social networks. Instead, they limit their interactions to family circles and local ones. This unwillingness to expand the scope of their interactions is not conducive to financing success (Burt 1997; Guiso et al. 2004; Eddleston et al. 2014; Javakhadze et al. 2016). Regardless of gender role types, all female entrepreneurs should gradually change their behavior, attempt to make friends, seek social resources, and make good use of social network relationships to increase financing opportunities (Guiso et al. 2004). Our research findings point out that androgyny and masculinity have a higher contribution to social capital, and therefore female entrepreneurs should develop certain androgynous and masculine traits to expand their social capital. Individual gender roles are no longer rigidly attached to biological sex in modern business field. Female entrepreneurs' masculine characteristics such as entrepreneurship, competition, tenacity, and independence are significant in careers of successful female entrepreneurs. Therefore, female entrepreneurs should no longer rigidly adhere to gender stereotypes and should begin to absorb positive masculine characteristics and overcome the limitations of traditional concepts of female roles. Awareness of helpful resources should be cultivated to expand their social networks, because this can contribute greatly to entrepreneurial success. Second, feminine characteristics such as kindness, integrity, inclusiveness, dedication, discretion, moderation, perseverance, and tenacity are associated with female entrepreneurs' biological sex. They should develop and exploit these characteristics with masculine traits when dealing with external financing. To start up a new business 
by borrowing from relatives and friends may be a good starting point, but to expand a business, the need for external financing is normally unavoidable and beneficial (Alsos et al. 2006). Thus, an expansive and effective social network driven by more masculine characteristics might be the key for a traditionally feminine entrepreneur to build a successful business via readily available external financing.

For government policies and society as a whole, our recommendations are as follows. Firstly, and considering that female entrepreneurs may still face difficulties from an institutional perspective when acquiring social capital, government should improve proper institutional support and policy supplements (Park et al. 2020) to encourage their willingness to seek external financing. Secondly, from the market perspective, gender equality should be protected to make sure that the financial environment is fair and just. Female entrepreneurs deserve to have effective guidance provided by the government (Wu et al. 2020). For example, it may be constructive to establish a network of organizations that support female entrepreneurship, especially the group with feminine and undifferentiated gender traits. Therefore, additional access to professional entrepreneurship lectures, skill upgrading, and vocational training should be made available to assist female entrepreneurs in gaining information more effectively as well as enhancing their willingness to choose external financing, which in the end will foster the development of capital markets. Thirdly, from the cultural perspective, society should encourage tolerance and openness by showing respect for female entrepreneurs who have various gender roles, to make sure that they can extend their social capital and acquire financial support according to their respective conditions.

\section{Limitations and future research}

Although this study makes meaningful contributions to the entrepreneurial theory and practice, like any other researches there are limitations. First, the sample that we used for this study is small due to budget constraints though it meets the minimum statistical requirement for inference. The sample is not nationwide but from Northern China, thus we might have missed some special characteristics from the female entrepreneurs in Southern and Western China. A wider national sample frame is definitely desirable to detect any such differences if there are any. Second, this study employs cross-sectional data that rely heavily on self-reporting. Despite vigorous efforts during the questionnaire design and data collection stage, as well as systemic statistical treatment, some bias may be inevitable. To verify the validity of the current study's findings, an experimental study or longitudinal study is definitely recommended to trace the pattern over a period of time to determine how different gender roles play out in those female entrepreneurs' success or failure. Considering that the emerging market phenomenon in China is only quite recent, in the past two decades, and that entrepreneurial cultural takes a longer time to take hold, a longer period of observation is needed in such a dynamic, changing environment to decipher the true behavior pattern of Chinese female entrepreneurs. Finally, we limited our study only to social capital as the intermediary to access the external financing. It is very possible that there are other intermediary effects other than social capital 
in this regard. Future studies should be directed to correct the above limitations. It is also recommended that future research needs to be conducted with female entrepreneurs in other countries to contrast the findings with those presented in this study.

Acknowledgements We would like to thank the editors, Prof. Fabian Jintae Froese and Prof. Jie Wu and anonymous reviewers for their insightful comments on the earlier drafts. The authors gratefully acknowledge the financial support by the Natural Sciences Foundation of China (Key Project \#71620107001) for this research project.

\section{Compliance with ethical standards}

Conflict of interest On behalf of all the authors, the corresponding author states that there are no conflicts of interests.

\section{References}

Alsos, G., Isaksen, E., \& Ljunggren, E. (2006). New venture financing and subsequent business growth in men-and women-led businesses. Entrepreneurship Theory and Practice, 30(5), 667-686.

Alsos, G., \& Ljunggren, E. (2017). The role of gender in entrepreneur-investor relationships: A signaling theory approach. Entrepreneurship Theory and Practice, 41(4), 567-590.

Ayyagari, M., Demirguc-Kunt, A., \& Maksimovic, V. (2008). How important are financing constraints? The role of finance in the business environment. The World Bank Economic Review, 22(3), 483-516.

Becker-Bhase, J., \& Sohl, J. (2007). Do women-owned businesses have equal access to angel capital? Journal of Business Venturing, 22(4), 503-521.

Bem, S. L. (1974). The measurement of psychological androgyny. Journal of Consulting and Clinical Psychology, 42(2), 155-162.

Bem, S. L. (1977). On the utility of alternative procedures for assessing psychological androgyny. Journal of Consulting and Clinical Psychology, 45(2), 196-205.

Bourdieu, P. (1986). The forms of capital. In J. Richardson (Ed.), Handbook of theory and research for the sociology of education (pp. 241-258). New York: Greenwood.

Burleson, B., Delia, J., \& Applegate, J. (1992). Effects of maternal communication and children's socialcognitive and communication skill on children's acceptance by peer group. Family Relations, 41(3), 264-272.

Burt, R. (1997). The contingent value of social capital. Administrative Science Quarterly, 42, 339-365.

Cai, L., Zhao, D., \& Zhu, X. (2005). Research on the characteristics of female entrepreneurs. Science and Management, 26(9), 43-47.

Constantinople, A. (1973). Masculinity-femininity: An exception to a famous dictum? Psychological Bulletin, 80, 389.

Dawn, I. (2008). Mediation analysis: Quantitative applications in the social sciences. London: Sage Publications Inc.

Denis, D. (2004). Entrepreneurial finance: An overview of the issues and evidence. Journal of Corporate Finance, 10, 301-326.

Eddleston, K., Ladge, J., Mitteness, C., \& Balachandra, L. (2014). Do you see what I see? Signaling effects of gender and firm characteristics on financing entrepreneurial ventures. Entrepreneurship Theory and Practice, 40, 489-514.

Fabowale, L., Orser, B., \& Riding, A. (1995). Gender, structural factors, and credit terms between Canadian small businesses and financial institutions". Entrepreneurship Theory and Practice, 19(4), 41-66.

Fay, M., \& Williams, L. (1993). Gender bias and the availability of business loans. Journal of Business Venturing, 8(4), 363-376.

Ferris, S., Javakhadze, D., \& Rajkovic, T. (2019). An international analysis of CEO social capital and corporate risk taking. European Financial Management, 25(1), 3-37.

Fischer, E. M., Reuber, A. R., \& Dyke, L. S. (1993). A theoretical overview and extension of research on sex, gender, and entrepreneurship. Journal of Business Venturing, 8, 151-168. 
Fukuyama, F. (1995). Trust: The social virtue and the creation of prosperity. Mankato: Free Press.

Global Entrepreneurship Monitor 2019 Report. Retrieved from https://www.gemconsortium.org/repor $\mathrm{t} / 50213$.

Greve, A., \& Salaff, J. (2003). Social networks and entrepreneurship. Entrepreneurship Theory and Practice, 28(1), 1-22.

Guan, P., \& Luo, D. (2009). The relationship between psychological capital of women entrepreneurs and venture growth in transition economies. Economic Management Journal, 8, 81-88.

Guiso, L., Sapienza, P., \& Zingales, L. (2004). The role of social capital in financial development. American Economic Review, 94(3), 526-556.

Hurun Report 2018. Retrieved from https://www.hurun.net/EN/Home/Index.

Iakovleva, T., Solesvik, M., \& Trifilova, A. (2013). Financial availability and government support for women entrepreneurs in transitional economies: Cases of Russia and Ukraine. Journal of Small Business and Enterprise Development, 20(2), 314-340.

Impavido, G. (1998). Credit rationing, group lending and optimal group size. Annals of Public and Cooperative Economics, 69(2), 243-260.

Javakhadze, D., Ferris, S., \& French, D. (2016). Social capital, investments, and external financing. Journal of Corporate Finance, 37, 38-55.

Jun, H.-J., \& Park, S. (2019). The effect of cross-level interaction between community factors and social capital among individuals on physical activity: Considering gender difference. International Journal of Environmental Research and Public Health, 16(3), 495.

Khoury, T., Junkunc, M., \& Deeds, D. (2013). The social construction of legitimacy through signaling social capital: Exploring the conditional value of alliances and underwriters at IPO. Entrepreneurship Theory and Practice, 37(3), 569-601.

Khwaja, A., \& Mian, A. (2005). Do lenders favor politically connected firms? Rent provision in an emerging financial market. The Quarterly Journal of Economics, 120(4), 1371-1412.

Lavine, L. O., \& Lombardo, J. P. (1984). Self-disclosure: Intimate and non-intimate disclosures to parents and best friends as a function of berm sex role category. Sex Role, 11, 735-744.

Li, C. (2012). Characteristics of gender role of women entrepreneurs. Collection of Women's Study, 1, 22-26.

Li, H. (2016). Develop sex role types and break interpersonal barriers. Journal of Henan Radio and TV University, 29(2), 110-112.

Lin, J. (2006). The research for function mechanism of social networks on the venture financing. Nankai Business Review, 9(4), 70-75.

Lin, Y., \& Su, X. (2005). Information, informal finance and SME financing. Economic Research Journal, $7,35-44$.

Liu, Q. (2008). A comparative study on the characteristics of Chinese and American female entrepreneurs, Working Paper.

Liu, Y., \& Froese, F. (2020). Crisis management, global challenges, and sustainable development from an Asian perspective. Asian Business \& Management, 19, 271-276.

Liu, Z. (2009). A study on the relationship between sex role and interpersonal problems of college students. Chinese Mental Health Journal, 26(9), 634-635.

Lu, Q., \& Su, Y. (2003). Revision of BEM sex role inventory. Chinese Mental Health Journal, 17(8), $50-553$.

Ma, H. (2010). Social capital and SME financing constraint. Economic Problems, 12, 68-72.

Manolova, T., Carter, N., \& Manev, I. (2007). The differential effect of men and women entrepreneurs' human capital and networking on growth expectancies in Bulgaria. Entrepreneurship Theory and Practice, 31(3), 407-426.

Marlow, S., \& Swail, J. (2014). Gender, risk and finance: Why can't a woman be more like a man? Entrepreneurship \& Regional Development, 26(1-2), 80-96.

Nahapiet, J., \& Ghoshal, S. (1998). Social capital, intellectual capital and the organization advantage. Academy of Management Review, 23(2), 242-266.

O'Gorman, C., \& Terjesen, S. (2006). Financing the Celtic tigress: Venture financing and informal investment in Ireland. Venture Capital, 8(1), 69-88.

Orser, B., Riding, A., \& Manley, K. (2006). Women entrepreneurs and financial capital. Entrepreneurship Theory and Practice, 30(5), 643-665.

Park, S., Lee, I., \& Kim, J. (2020). Government support and small- and medium-sized enterprise (SME) performance: The moderating effects of diagnostic and support services. Asian Business and Management, 19(2), 213-238. 
Petersen, M., \& Rajan, R. (1994). The effect of credit market competition on lending relationships. Journal of Finance, 49(3), 1091-1091.

Pleck, J. H. (1987). The theory of male sex-role identity: Its rise and fall, 1936 to the present. In H. Brod (Ed.), The making of masculinities: The new men's studies. Boston: Allen Unwin.

Plotnikova, M., Romero, I., \& Martínez-Román, J. A. (2016). Process innovation in small businesses: The self-employed as entrepreneurs. Small Business Economics, 47(4), 939-954.

Podsakoff, P., MacKenzie, S., Podsakoff, N., \& Lee, J. Y. (2003). Common method biases in behavioral research: A critical review of the literature and recommended remedies. Journal of Applied Psychology, 88(5), 879-903.

Portes, A. (1998). Social capital: Its origins and applications in modern sociology. Annual Review of Sociology, 24, 1-24.

Portes, A., \& Sensenbrenner, J. (1993). Embeddedness and immigration: Notes on the social capital determinants of economic action. American Journal of Sociology, 98, 1320-1350.

Preacher, K., \& Hayes, A. (2004). SPSS and SAS procedures for estimating indirect effects in simple mediation models. Behavior Research Methods, Instruments, \& Computers, 36(4), 717-731.

Putnam, R. (1993). Making democracy work: Critic tradition in modern society. Princeton: Princeton University Press.

Rienda, L., Claver, E., \& Quer, D. (2013). The internationalization of Indian multinationals: Determinants of expansion through acquisitions. Journal of the Asia Pacific Economy, 18(1), 115-132.

Saparito, P., Elam, A., \& Brush, C. (2013). Bank-firm relationships: Do perceptions vary by gender? Entrepreneurship Theory and Practice, 37(4), 837-858.

Schumpeter, J. A. (1947). The creative response in economic history. Journal of Economic History., 7(2), $149-159$.

Shaffer, D. R., Pegalis, L., \& Cornell, D. P. (1991). Interactive effects of social context and sex role identity on female self-disclosure during the acquaintance process. Sex Role, 24, 19.

Shin, Y., Chang, J., Jeon, K., \& Kim, H. (2019). Female directors on the board and investment efficiency: Evidence from Korea. Asian Business \& Management. https://doi.org/10.1057/s41291-019-00066 -2 .

Spence, J., Helmreich, R., \& Stapp, J. (1975). Ratings of self and peers on sex role attributes and their relation to self-esteem and conceptions of masculinity and femininity. Journal of Personality and Social Psychology, 32(1), 29-39.

Steel, J. L. (1991). Interpersonal correlated of trust and self-disclosure. Psychological Reports, 68, 1319-1320.

Terman, L., \& Miles, C. (1936). Sex and personality: Studies in masculinity and femininity. American Journal of Sociology, 12(1), 600-603.

Verheul, I., \& Thurik, R. (2001). Start-up capital: Does gender matter. Small Business Economics, 16(4), $329-346$.

Wang, D. (2006). The relationship between sex roles and motivation to manage-study on the barriers in the women's career development. Beijing: Capital University of Economics and Business.

Wang, L. (2011). A study on the relationship between sex role types and interpersonal relationship of middle school students. Journal of Campus Life \& Mental Health, 9(2), 89-91.

Wang, L. (2012). A study on the relationship between gender role and interpersonal harmony degree. Journal of Xinyu University, 17(4), 42-44.

Wang, X., Deng, S., \& Alon, I. (2011). Framework for female entrepreneurship in China. International Journal of Business and Emerging Markets, 3(1), 3-20.

Wang, X., Fan, G., \& Yu, J. (2017). China's Provincial Marketization Index Report. Beijing: Social Sciences Literature Press.

Watson, J. B. (1930). Behaviorism (revised ed.). Chicago: University of Chicago Press.

Wei, Y. (2014). A study on sex roles, trust and self-esteem of college students. Ability and Wisdom, 17, $116-116$.

Williams, D. W., \& Grégoire, D. A. (2015). Seeking commonalities or avoiding differences? Re-conceptualizing distance and its effects on internationalization decisions. Journal of International Business Studies, 46(3), 253-284.

Wu, J., Si, S., \& Yan, H. (2020). Reducing poverty through the shared economy: Creating inclusive entrepreneurship around institutional voids in China. Asian Business \& Management. https://doi. org/10.1057/s41291-020-00113-3.

Xu, Y., Ma, S., \& Liu, X. (2014). The relationship between sex role types and friendship quality of middle school students. Mental Health Education in Primary and Secondary School, 10, 23-26. 
Yao, Z., Cheng, Y., \& Jin, L. (2012). Research on functioning mechanism of financing motivation influencing growth of entrepreneur firms: A theoretical analysis framework. China Management Magazine, 6, 3-18.

Zhang, F., \& Chen, J. (2002). Knowledge creation -the core of enterprise knowledge management. Science of Science and Management of $S \&$ T, 10(25), 36-40.

Zhang, M., \& Li, Y. (2013). Research on the impact of system environment on the financing approaches. The Contemporary Economics, 35(4), 42-52.

Zhang, X., Xu, H., \& Zhang, Q. (2016). Research on financing of female entrepreneurs: Based on regional differences. Economists, 4, 14-15.

Zhao, L., Ren, J., \& He, H. (2013). Research on the construction of financing innovation network of SME from the perspective of social network. Science \& Technology Progress and Policy, 30(18), 152-155.

Zhao, X., Lynch, J., \& Chen, Q. (2010). Reconsidering Baron and Kenny: Myths and truths about mediation analysis. Journal of Consumer Research, 37(2), 197-206.

Zhu, X., \& Fei, Y. (2010). Empirical analysis of relationship characteristic, resource acquisition and new firm performance. Nankai Business Review, 13(3), 125-135.

Publisher's Note Springer Nature remains neutral with regard to jurisdictional claims in published maps and institutional affiliations.

Xu Wang is Professor of Accounting at Jilin University Management School. She has published one book and more than 30 scholarly articles in the International Journal of Business and Emerging Markets, Science Research Management, Social Science Front, Seeking Truth, among other publications. Her research interests concern entrepreneurship and corporate governance in China.

Li Cai is Professor of Management and the Director of Innovation and Entrepreneurship Research Institute at Jilin University. She is also the vice-chairman of Chinese Association for Science of Science and S\&T Policy, and a member of Advisory Committee of National Natural Science Foundation. She is a winner of National Outstanding Youth Fund and a National candidate for New Century Million Talents Project (first batch). She has won more than 10 Scientific and Technological Progress Awards and Outstanding Achievement Awards in Scientific Research. Her major research interests are innovative and entrepreneurial management. She has been in charge of over 10 projects of National Natural Science Foundation of China (NSFC) and has published more than 100 papers, 7 monographs and 1 translation.

Xiumei Zhu is Professor of Management at the School of Management, Jilin University. She has published two books and more than 70 scholarly papers in the international journals such as Leadership \& Organization Development Journal, International Entrepreneurship Management Journal, Systems Research and Behavioral Science and Management World. Her research interests concern entrepreneurship and innovation management.

Shengliang Deng is Professor of Marketing and International Business at the Goodman School of Business, Brock University, Canada. He has published eight books and numerous scholarly articles in publications including the European Journal of Operational Research, Journal of World Business, Journal of International Marketing, European Journal of Marketing, Journal of Marketing Management, Journal of Business Research, Management Decision, Internet Research, Tourism Management, Journal of Business and Industrial Marketing and the International Journal of Hospitality Management. His research interests concern international business strategy and marketing issues in emerging economies, especially China. 